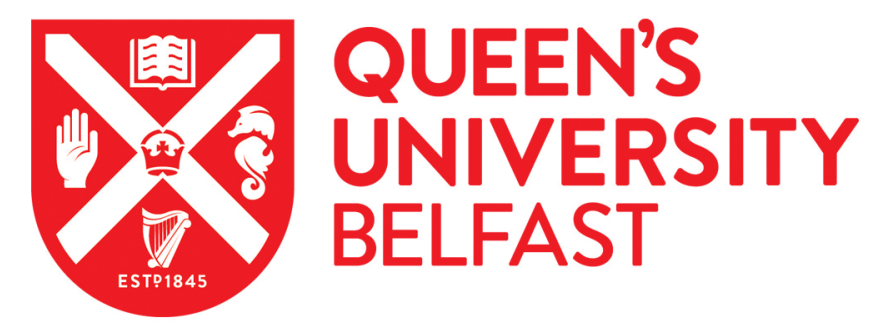

\title{
What is the availability of iodised salt in supermarkets on the Island of Ireland?
}

Shaw, M., Nugent, A. P., McNulty, B. A., Walton, J., McHugh, M., Kane, A., Moore Heslin, A., Morrissey, E., Mullan, K., \& Woodside, J. V. (2019). What is the availability of iodised salt in supermarkets on the Island of Ireland? European Journal of Clinical Nutrition.

Published in:

European Journal of Clinical Nutrition

Document Version:

Peer reviewed version

Queen's University Belfast - Research Portal:

Link to publication record in Queen's University Belfast Research Portal

Publisher rights

(C) Springer Nature Limited 2019. This work is made available online in accordance with the publisher's policies. Please refer to any applicable terms of use of the publisher.

\section{General rights}

Copyright for the publications made accessible via the Queen's University Belfast Research Portal is retained by the author(s) and / or other copyright owners and it is a condition of accessing these publications that users recognise and abide by the legal requirements associated with these rights.

Take down policy

The Research Portal is Queen's institutional repository that provides access to Queen's research output. Every effort has been made to ensure that content in the Research Portal does not infringe any person's rights, or applicable UK laws. If you discover content in the Research Portal that you believe breaches copyright or violates any law, please contact openaccess@qub.ac.uk. 


\section{What is the availability of iodised salt in supermarkets on the}

\section{Island of Ireland?}

Mark Shaw ${ }^{1}$, Anne P. Nugent ${ }^{2}$, Breige A. McNulty ${ }^{3}$, Janette Walton $^{4}$, Michaela McHugh $^{1}$, Ashley $^{2}$ Kane $^{1}$, Aoibhin Moore Heslin ${ }^{3}$, Eoin Morrissey ${ }^{4}$, Karen Mullan ${ }^{5}$, Jayne V. Woodside ${ }^{1}$

${ }^{1}$ Institute for Global Food Security, Centre for Public Health, School of Medicine, Dentistry and Biomedical Sciences, Queen's University Belfast, Belfast.

${ }^{2}$ Institute for Global Food Security, School of Biological Sciences, Queen's University Belfast, Belfast. ${ }^{3}$ Institute of Food and Health, School of Agriculture and Food Science, University College Dublin, Dublin 4, Ireland.

${ }^{4}$ Department of Biological Sciences, Cork Institute of Technology, Cork, Ireland

${ }^{5}$ Regional Centre for Endocrinology \& Diabetes, Belfast Health \& Social Care Trust

\section{Corresponding Author}

Professor Jayne Woodside,

Institute for Global Food Security (Centre for Public Health),

School of Medicine, Dentistry and Biomedical Sciences,

Queen's University Belfast,

Institute of Clinical Science A (First Floor)

Grosvenor Road

Belfast

BT12 6BJ 
UK

Email: j.woodside@qub.ac.uk

Running title: lodised salt availability on the Island of Ireland 


\section{Abstract}

lodine deficiency remains a global nutritional public health challenge, with evidence suggesting borderline adequate or even deficient status for UK and Irish subpopulations such as schoolgirls and pregnant women. The solution, according to the WHO, is salt iodisation, but it is not known how widely available iodised salt is in supermarkets. lodised salt availability was determined by a shelf survey of 89 supermarket stores on the island of Ireland ( $n=30$ in Northern Ireland and $n=59$ in the Republic of Ireland) from September 2018-January 2019, to take into account factors such as store type, location, population density, socioeconomic status and ethnicity. Availability was calculated as the number of stores selling iodised salt as a percentage of the total. lodised salt was only available in 11 stores (12\%), of which 10 were ethnic stores. This indicates a lack of access for the majority of the Irish and Northern Irish populations. 


\section{Introduction}

lodine deficiency disorders are caused by lack of iodine, with their health effects well-described (1). There is no harmonised European approach to ensure adequate population dietary iodine intakes (2). Europe has the lowest uptake of salt iodisation globally; the form of iodine fortification recommended by the World Health Organisation (2). This is possibly due to concerns that iodisation may undercut population-level efforts to reduce salt intakes and, consequently, hypertension (2). Neither the UK nor Ireland has ever had a salt iodisation policy, with dietary iodine relying heavily on adventitious intakes, particularly from dairy produce where presence of iodine in cleaning solutions or in animal feed has historically led to iodine entering milk and dairy produce $(2,3)$. Without any iodised salt policy, a number of studies have investigated iodine intake and status in UK and Irish populations, suggesting some concern (4-8). This against a background where there has been a rise in non-dairy milk alternatives which may not contain iodine (9). lodised salt availability has been demonstrated to be low in the UK and Northern Ireland (NI) (10), but has not been explored across the Island of Ireland (Iol). The aim of this study was to survey iodised salt availability in supermarkets in $\mathrm{NI}$ and the Republic of Ireland (Rol). 


\section{Methods}

lodised salt availability was ascertained by a supermarket shelf survey method through undertaking supermarket audits to check in-store salt availability, and browsing supermarket websites to check online availability from September 2018-January 2019. Visits occurred in four geographical areas in NI and six in Rol. These were selected to cover densely (urban) and more sparsely (rural) populated regions, and included areas with populations of diverse socioeconomic status and ethnicity. In all geographic areas, all available stores were inspected, including supermarkets, smaller convenience stores and ethnic stores (European, Asian and African). A database was created to document on-pack details, and each store was categorised by the following supermarket type: retail giant, discounter, convenience store and ethnic store. A total of 89 stores were included overall.

Data were collected on the weight of salt available in grams, cost of salt per kilogram (in either pound sterling $(€)$ or euros $(€)$, ingredients, manufacturer, presence and concentration $(\mu \mathrm{g} / 100 \mathrm{~g})$ of iodine. The availability of iodised salt was calculated using the number of stores selling iodised salt as a percentage of the total number of stores investigated. 


\section{Results}

lodised salt was available in eleven of the eighty-nine supermarkets ( $12.4 \%$ of total) investigated, with three of these being in $\mathrm{NI}$ and eight in the Rol (Table 1). Fifty-six stores were surveyed in the three main cities (Belfast, Dublin, Cork), of which $16.1 \%$ stocked iodised salt; only 2 stores outside of these cities (out of 33 surveyed) sold iodised salt (6.1\% of stores visited). lodised salt was generally not found in mainstream supermarkets, but was present in a much higher percentage of ethnic stores ( $50 \%$ of stores surveyed, $n=20$ ), especially those of Eastern European origin (66.6\% of stores surveyed, $\mathrm{n}=12$ ). Sainsbury's (NI) was the only non-ethnic store selling iodised salt but, even then, this was only present in one of the two Sainsbury's stores surveyed. There were 19 unique brands of iodised salt available. In Sainsbury's the sole brand was Cerebos (Premier Foods Group), while there were 18 unique iodine-containing brands in ethnic stores. The iodine concentration also differed, with Cerebos containing $1150 \mu \mathrm{g} / 100 \mathrm{~g}$, while the ethnic brands contained 1268-3026 $\mu \mathrm{g} / 100 \mathrm{~g}$.

The cost of iodised salt ranged from $£ 2.38 / \mathrm{kg}$ to $£ 41.50 / \mathrm{kg}$ in NI and from $€ 0.50 / \mathrm{kg}$ to $€ 6.33 / \mathrm{kg}$ in Rol. In contrast, standard salt sold for $£ 0.36 / \mathrm{kg}$ in $\mathrm{NI}$ and $€ 0.37 / \mathrm{kg}$ in Rol: making iodised salt $6.6-115.3$ times more expensive in $\mathrm{NI}$, and 1.4-12.7 times more expensive in Rol than standard salt. 


\section{Discussion}

lodised salt is not widely available for purchase on lol. lodised salt was present in only $12 \%$ of all stores audited, being more available in cities and in ethnic supermarkets. Prices were higher than for standard table salt, and brands contained differing iodine concentrations. Given the apparent low market share of ethnic supermarkets, this indicates that iodised salt is not widely accessible or available on the lol.

A previous shelf survey of major supermarket stores in the UK and NI identified that $42 \%$ of the 75 stores checked contained iodised salt, which, when accounting for market share, yielded a weighted availability figure of $22 \%(10)$. Although the present survey included many of the same stores (Tesco, Lidl, Asda, Sainsbury's), iodised salt was only present once (Sainsbury's), indicating that the majority of shoppers on lol cannot buy iodised salt. Of note, we report availability of iodised salt in some ethnic stores and note that ethnic stores were not surveyed previously (10). Given the lack of data on market share of ethnic supermarkets, we could not complete weighted availability, but it would appear that there is an inverse relationship between market share and iodised salt availability.

The level of iodised salt consumption by UK and Irish shoppers and/or their awareness of iodised salt and its health implications is unknown. The brands of iodised salt identified here contained variable amounts of iodine and were more expensive than standard varieties. Given the WHO recommendation for adoption of salt iodisation in Europe, there is a need to engage with consumers, policymakers and industry to understand opinions on iodised salt use, and to assess whether the growing popularity of veganism and non-dairy milk alternatives is indirectly promoting iodine deficiency, due to the low levels (or lack of) iodine in non-dairy milk alternatives.

Strengths of the study were inclusion of supermarkets in areas of differing population density across Iol, including ethnic stores. However we acknowledge the survey was not exhaustive, results were 
limited to a period of 4-5 months and we were unable to complete weighted availability analysis due lack of market share data for all contributing supermarket types.

In conclusion, iodised salt availability is low on Iol, and neither the UK nor Ireland have iodine fortification programmes. Current availability is limited to ethnic supermarkets. There remains a need to monitor iodine status and to investigate stakeholder knowledge and attitudes to salt iodisation.

Acknowledgements: None

Conflict of Interest: No conflict of interest to declare.

Author Contributions: APN, BMcN, JW and JVW designed the study. MS, APN, BMcN, JW, MMcH, AK, AMH, EM and JVW completed the store audits. MS complied the overall database and analysed the data. MS, APN and JVW completed quality control checks and wrote the initial manuscript. All authors contributed to data interpretation and writing of the paper.

Funding: This study was supported by the lodine Global Network. 


\section{References}

1. http://www.ign.org/2-why-do-we-need-iodine.htm

2. Anderson M, de Benoist B, Darton-Hill I, Delange F. (editors) lodine Deficiency in Europe: A Continuing Public Health Problem. 2007. Geneva: WHO and UNICEF.

3. O'Kane SM, Pourshahidi K, Mulhern MS, Weir RR, Hill SH, O'Reilly J, et al. The Effect of Processing on the lodine and Selenium Concentration of Cow's Milk Produced in Northern Ireland (NI): Implications for Population Dietary Intake. Nutrients. 2018; 10,3: 287

4. McNulty BA, Nugent AP, Walton J, Flynn A, Tlustos C, Gibney MJ. lodine Intake and status in Irish adults: is there cause for concern? BJN. 2017; 117, 3: 422-431.

5. Bath SC, Walter A, Taylor A, Wright J, Rayman MP. lodine deficiency in pregnant women living in the South-East of the UK: the influence of diet and nutritional supplements on iodine status. BJN. 2014; 111, 9: 1622-1631.

6. Vanderpump MP, Lazarus JH, Smyth PP, Laurberg P, Holder RL, Boelaert K et al. lodine status of UK schoolgirls: a cross-sectional survey. Lancet. 2011; 377, 2007-2012

7. McMullan P, Hamill L, Doolan K, Hunter A, McCance D, Patterson C, et al. lodine deficiency among pregnant women living in Northern Ireland. Clin Endocrinol (Oxf). 2019 Jul 19. doi: 10.1111/cen.14065. [Epub ahead of print]

8. Mullan K, Hamill L, Doolan K, Young I, Smyth P, Flynn A, et al. lodine status of teenage girls on the island of Ireland. Eur J Nutr. 2019 Jul 18. doi: 10.1007/s00394-019-02037-x. [Epub ahead of print]

9. Bath SC, Hill S, Infante HG, Elghul S, Nezianya CJ, Rayman MP. Iodine concentration of milkalternative drinks available in the UK in comparison to cows' milk. BJN. 2017; 118, 7: 525532 
10. Bath SC, Button S, Rayman MP. Availability of lodised table salt in the UK - is it likely to influence population iodine intake? PHN. 2013; 17, 2: 450-454

\section{Table legends}

Table 1: lodised salt availability according to shop type from a survey of supermarket stores on the Island of Ireland between September 2018 and January 2019 


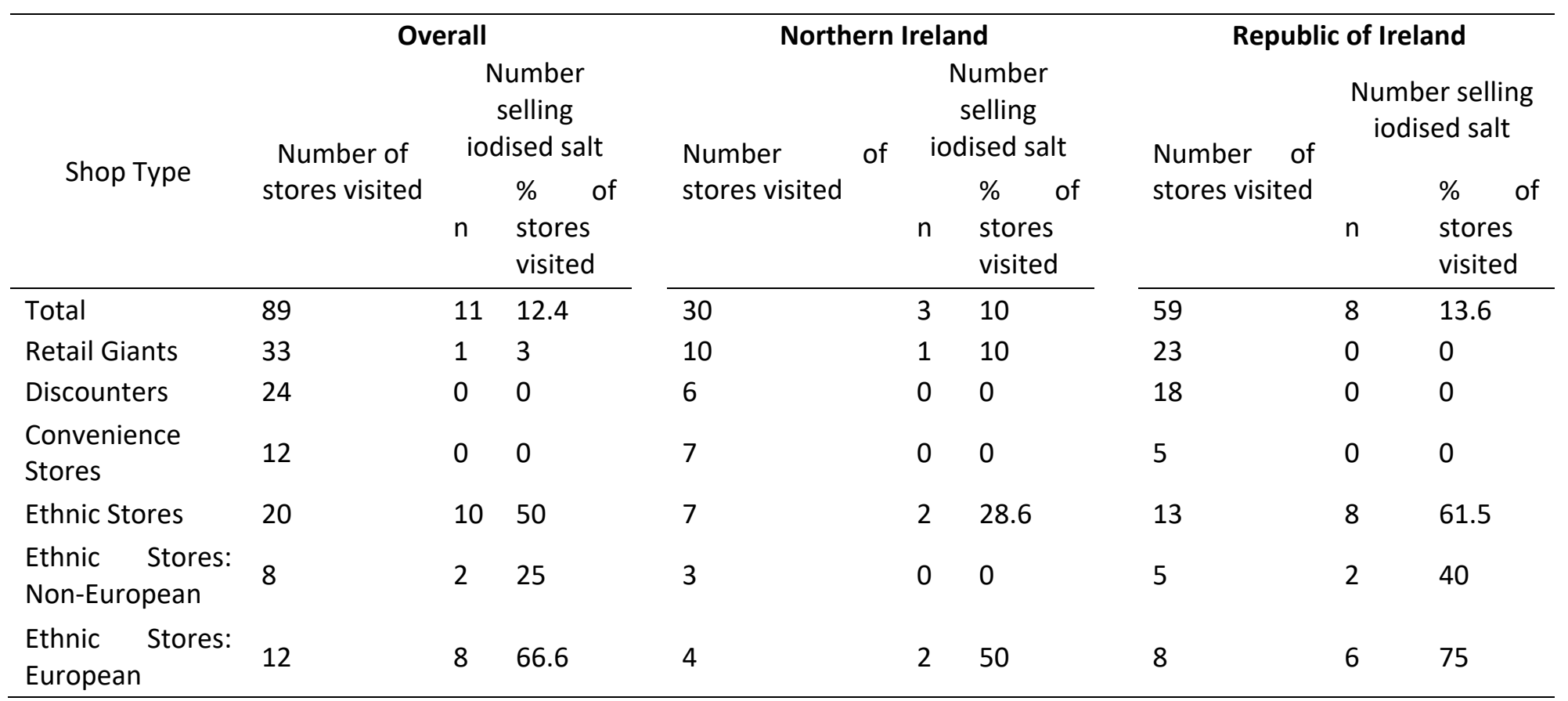

